\title{
Teachers and The Application of Constructivism Learning: What Their Relationship is
}

\author{
Rahayu Pratiwi \\ Postgraduate Mathematics Education \\ Yogyakarta State University \\ Indonesia \\ rahayu.pratiwi2016@student.uny.ac.id
}

\author{
Jailani \\ Mathematics Education \\ Yogyakarta State University \\ Indonesia \\ jailani@uny.ac.id
}

\begin{abstract}
Educational expert is teachers. Teachers need the skills to implement their work optimally. The skills have several standards, one of them is the competence of practice. The competence of practice is how the teacher implements the learning process effectively. Effective learning will occur if the learning method used in suitable with the needs of students. Students need a teacher who can facilitate learning. Learning can be done in various ways, namely by using habits, reinforcement, even from within yourself by using a mind that can construct new knowledge by beginning with existing knowledge with new experiences and then generate conclusions that make it a new knowledge. The process of constructing new knowledge is known as the theory of constructivism learning. This process will not work properly teachers do not have competence of practice. Basically in this competence has a standard of appearance through the practice and social competence of a teacher.
\end{abstract}

\section{Keywords—teacher's competence; constructivism learning}

\section{INTRODUCTION}

Generally, the implementation of education system requires the role of teachers. A teacher is a person whose professional activity involves the planning, organising and conducting of group activities to develop students' knowledge, skills and attitudes as stipulated by educational programs [1]. Activities covered in the education program will run optimally if the teacher has sufficient knowledge. The knowledge itself is contained in the competence of teachers. The competence of the teacher may indicate the teacher's professionalism in carrying out his/ her duties. The teacher must have sufficient professional competence and an elaborated comprehensive plan of personality development, which focuses on the development of morality, sociability, character and respect for the cultural and environmental values [2].

Science which contains knowledge and skills on teacher competence is implied in the form of action. Knowledge in action is the knowledge of professional teachers used in everyday practices [3]. The practice of a teacher is to teach and educate students on the learning process in the classroom. Competence related to the practice of a teacher in learning mathematics is called the competence of mathematical practice. The competence of mathematical practice plays a role in improving students' mathematics learning outcomes by evaluating the teacher's practice and making it a source that informs the teacher's performance which aims to develop improvements in learning [4]. Not only students, teachers must also learn continuously because the knowledge will continue to grow according to the era. Moreover, the world has entered the globalization era in this 21 st century, which then requires teachers to innovate continuously.

In the 21 st century, the development of technology and information occurs rapidly. In fact, almost every students in high school have their own gadgets. Information on the use of gadgets is not given in the direct learning process, but students obtained their own knowledge. For instance, by experimenting something, asking questions towards people around them, reading the user manual and browsing the internet. Based on this fact, students actually learn how to use gadgets by constructing their own knowledge, which is through the 'trial and error' experience, and connect the knowledge they have known with the new knowledge they obtained through questions given towards the people around them.

The example above shows that students can gain their own knowledge quickly. The knowledge acquired is then constructed in their own mind, therefore a new understanding arises. It is a part of the constructivism theory. Constructivism is the stream of knowledge philosophy which emphasizes that knowledge is the result of construction (formation) [5]. This stream of philosophy can also be applied in the learning process. The application of this philosophy stream in learning process is known as constructivism learning theory.

Learning with constructivism theory is expected to achieve educational goals. The purpose of education is aligned with the four pillars of education according to UNESCO, which are, "(1) learning to know: to provide the cognitive tools required to better comprehend the world and its complexities, and to provide an appropriate and adequate foundation for future learning; (2) learning to do: to provide the skills that would enable individuals to effectively participate in the global economy and society; (3) learning to be: to provide self-analytical and social skills to enable individuals to develop to their fullest potential psychosocially, affectively as well as physically, for a all-round 'complete person; (4) learning to live together: to expose individuals to the values implicit within human rights, democratic principles, intercultural understanding and respect 
and peace at all levels of society and human relationships to enable individuals and societies to live in peace and harmony" [6]. The application of this learning theory has been widely practiced by teachers in the classroom. But not all the teachers has been aware about the meaning and purpose of learning with this theory. Therefore, researchers are interested to discuss about the competence of teachers, particularly the practice of mathematics, constructivism learning and the relationship between the two.

\section{TEACHER'S COMPETENCE}

Competence is a science which must be mastered by professional experts in carrying out their duties. Competence is a set of basic knowledge, skills and values reflected in the thinking and acting habits of a professional person [7]. Professionals in education are teachers.

Teacher's competence is the ability, expertise and skill possessed by professional teacher to facilitate themselves in carrying out their duties [7][8][9]. The main task of the teacher is to educate and teach students to learn, to makes students change to be a better person in the aspects of attitude, skills and knowledge. It is clearer that the combination of attitudes, knowledge, comprehension and skills denote the core of the competencies in which the combination is applied through action in the relevant situation [10]. The combination is used to perform the action in learning processes, particularly in the subject of mathematics. Such actions are called mathematical practices.

The competence of teachers which supports mathematical practice consists of various standards. These competence standards include content knowledge, mathematical practices, content pedagogy, mathematical learning environment, impact on student learning, professional knowledge and skills, secondary mathematics field experiences and clinical practice [11]. Of the seven competency standards, mathematical practices play an important role. Without the competence standard of mathematical practices, other competency standards are merely theoretical and cannot be applied as the task of the teacher, i.e the practice.

The competence of practice involves the performance, social and mathematical practice competency standard itself. Performance standards involve the appearance of teachers in teaching [7]. Social standard is the ability of teachers as a part of the community to communicate and interact effectively with students, fellow teachers, education personnel, parents and the community [12]. Competence of mathematical practices is a competency in which high school math teachers are effectively solving the problems; representing ideas, reasons, mathematical proofs; using mathematical models; concerning accuracy; identifying structural elements, generalizing, making mathematical communication and making connections as meaningful mathematical applications [11]. As a whole, it can be concluded that the competence of mathematical practice is a standard of competence which consists of performance standard through practice and social competence of a teacher, i.e having the ability to solve problems, present ideas and mathematical proof, use mathematical model, concern on the accuracy, identify structural element, generalize, make mathematical communications, as well as communicate and socialize effectively with students, fellow teachers, parents and students [7][11][12][13].

\section{CONSTRUCTIVISM LEARNING}

Constructivism is one of the philosophy streams. This stream of philosophy has an effect on the field of education. Constructivism in education is known as constructivism learning theory. Constructivism learning theory is pioneered by Jean Piaget, Vygotsky and Ausubel. According to Piaget, constructivism learning theory can not be separated from cognitive development. Cognitive development depends on four factors, namely biological growth, experience with the physical environment, experience with social environment and equilibrium [14]. Vygotsky as a disciple of constructivism learning theory has given more emphasis towards the social environment as a facilitator of development and learning process [15]. Constructivism learning theory by Ausubel involves meaningfulness. Meaningful learning process is a process of linking new information's towards relevant concepts contained in a person's cognitive structure [16].

Learning cannot be separated from the apparent problems to find its solution. Problems cannot be solved by getting correct answers through memorization. But to solve the problem intelligently, students must have the point of view that the problem is experienced by the student itself. Therefore students will have the desire to find a way or solution to solve the problem. The students solve these problems by constructing the existing knowledge and new experiences gained in order to gain new knowledge. The essence of the learning process is that students construct or build their own knowledge by involving experience and prior knowledge. Such learning process is called constructivist learning.

Several experts claimed an explanation of constructivism. Karagiorgi and Symeou (2005) mentioned that "Constructivism involves one's experience"[17]. In constructivism, learning is represented as a constructive process in which the learner is building an internal illustration of knowledge, a personal interpretation of experience [18].

Brooks and Brooks revealed that "Constructivism is not a theory about teaching. It is a theory about knowledge and learning. The theory defines knowledge as temporary, developmental, socially and culturally mediated, and thus, nonobjectie" [19]. With different point of view, Bada stated that the central to the tenet of constructivism is that learning is an active process [20]. Information may be imposed, but understanding cannot be, for it must come from within. Constructivism requires a teacher to act as a facilitator whose main function is to help students become active participants in their learning and make meaningful connections between prior knowledge, new knowledge, and the processes involved in learning. 
The application of learning process with constructivism learning theory has several benefits. These benefits are as follows [20].

- Students learn more and enjoy more when students are actively engaged in the learning process, rather than being passive listeners.

- Education will work best when it is concentrated on thinking and understanding, not by memorizing, constructivism concentrates on how to think and understand.

- Constructivist learning is transferable. In constructivist classrooms, students create organization principles. Students can bring the organization to other learning settings.

- Constructivism provides the ownership towards the students of what they have learned, because learning is based on the student's questions and exploration, students frequently take part in designing the assessment as well. Constructive assessment involves student's initiative and teacher's personal investment in journals, physical mode of research reports and artistic representations. Creative instinctive involvement can develop students' ability to communicate their knowledge in various ways. Students tend to retain and transfer their new knowledge apparently in life.

- Based on learning activities with authentic real contexts, constructivism stimulates and engages students. Students in constructivist class, learn to question several matters and to apply curiosity naturally.

- Constructivism can develop social and communication skills by creating classroom environment that emphasizes collaboration and exchange of opinion. Students must learn how to articulate their opinions clearly and collaborate it in completing their tasks effectively with various projects in groups.

In the application of learning with constructivism, students are required to construct or build their own knowledge that they desired to explore, assisted with the learning experience from the learning process designed by the teacher as a facilitator and mediator when the learning process takes place. Learning design includes approaches and learning models in accordance with the teaching materials which will be given. The approach and learning model that has the same principles with constructivism learning theory is as follows.

\section{A. Learning Approachs}

1) Scientific approach: Scientific approach is a learning method or mechanism to facilitate students in obtaining knowledge or skill by procedures based on a scientific method [21]. The scientific method is neither distinguishable from everyday activities nor particulary powerful when used in this manner because the mechanism explaining the pattern remains unknown, regardless of the tool used to observe the pattern [22]. The explanation implies that the scientific approach is a learning process by scientific method in which the activities carried out are daily activities. Scientific approach has several characteristics that distinguish it from other approaches, namely: (1) learning is directed to encourage students in determining various sources of learning by making observations, rather than being informed; (2) learning is directed/ for the ability to formulate a problem (ask) rather than to solve a problem (answer); (3) learning is directed to train analytical thinking (decision-making) rather than mechanistic thinking (routine); and (4) learning emphasizes the importance of cooperation and collaboration in solving problems [21]. Characteristics above refers that students are required to establish their own knowledge. This is aligned with constructivism learning theory.

2) Realistic mathematics education approach: Realistic mathematical learning is basically the utilization of reality and environment which students understand to expedite the process of learning mathematics, in order to achieve preferable mathematics education goals [23]. While Frudenthal claimed that in realistic instruction, learning is a task which proceeds from reality, that is from the growing inner environment, in which horizontal mathematization are required formerly. Two criteria have been selected for mathematics education, namely horizontal and vertical mathematics [24]. Mathematization can not be separated from the approach of realistic mathematics education, this makes it a characteristic. In realistic mathematics instruction, careful attention is paid to both the horizontal and the vertical component of mathematizing [25]. Horizontal mathematization is the process by which the students use math in order to assist themselves in organizing and solving a problem in a real situations. While vertical mathematization is the process of reorganizing by using mathematics itself [26]. The process of mathematization will be significant for students if the students are active and independent in the learning process. If it is performed, then unconsciously students have constructed knowledge with their own thoughts and abilities. Teachers play a deeper role in facilitating and motivating students when the learning process takes place. Realistic mathematics education approach is a process of learning by utilizing reality which has been experienced or conceivable by students to achieve the purpose of learning mathematics. The process of learning mathematics with this approach begins with horizontal mathematization. After the learning process enters the horizontal mathematization, it will proceed to the vertical mathematization.

3) Contextual Approach: Contextual approach is derived from a constructivist approach [27]. Contextual learning is a concept that assist teachers to connect the subject with realworld situations [28]. The concept in question is a concept that emphasizes the relationship between learning materials with the real life of students, therefore students are able to connect and apply the competence of learning outcomes in their everyday life through the process of applying competence in everyday life, students will perceived the importance of learning and they will obtain deep significance in what they have learned [9]. Thus, learning with contextual approach is a learning process 
which emphasizes that learning material are related to the real life. This definition bring forth several principles contained in the contextual learning approach. The principles of contextual learning approach are as follows: (1) interdependence, i.e making meaningful connections between the learning process and the real life context; (2) differences, i.e encouraging students to generate diversity, distinction and uniqueness; (3) self-regulation, i.e the learning processes are regulated, maintained and realized by the students themselves in order to realize all of their potential; (4) authentic assessment, i.e to challenge students in order to apply various academic informations and their own skills into contextual situations significantly [29].

\section{B. Learning Models}

1) Problem-based learning model: Problem-based learning is a pedagogical technique which locates learning in the context of complex problem solving [30]. Problem-based learning (PBL) is a learning process which uses ill-structured and open authentic learning problems as a context for learners to develop problem-solving skills and critical thinking as well as to establish new knowledge (Hosnan, 2014). Thus, problem-based learning model is a learning process which uses real problems as its focus, which aims to develop the capabilities of the students. This learning model has several characteristics that seems to be practiced immediately in the classroom. These characteristics are: (1) proposing a problem or question; (2) linkages with various problems and disciplines; (3) authentic investigation; (4) producing and presenting results or works; and (5) collaboration [31].

2) Project-based learning model: Project-based learning model do not differ significantly from the prior learning model, the only matter is that the problem given by the teacher towards the students are in the form of project. Project-based learning model is a problem-based learning with the use of a project that results in the emergence of various learning outcomes beyond what is anticipated [32]. Learning is dynamic because students use various processes and methods to explore the projects. Project-based learning (PBL) is a learning strategy that uses projects or activities as a means of learning to attain attitude, knowledge and skills competencies [31]. Project-based learning model is a problem-based learning process that makes the project a problem and/or solution to a problem, which becomes the characteristic of this learning model.

3) Discovery learning model: Discovery learning model as a learning process which occurs when the students are not presented with the final form of the lesson, but through the process of discovering something [33]. Students are expected to organize their own learning experiences. The benefits gained from the learning experience through discovery includes: (1) the improvement of intellectual potential; (2) a shift from extrinsic appreciation to intrinsic appreciation; (3) studying the heuristics of the discovery; and (4) assistance for memory processing (Bruner, 1961). Discovery learning model has its main characteristics, namely: (1) exploring and solving problems to create, combine and generalize knowledge; (2) student-centered; and (3) activities to combine new knowledge and existing knowledge [31]. Thus, it can be concluded that the discovery learning model is a teacher-designed learning with the discovery stage, either discovering new knowledge through the process or the final result of the learning experience.

4) Cooperative learning model: Cooperative learning is a learning process which involve the use of small groups that enables the students to work simultaneously within the group in order to maximize their own learning process and the learning process from one another [34]. Cooperative learning is a learning model in which students learn to cooperate with small groups collaboratively with 4-6 people by heterogeneous structures [33]. The essential components in cooperative learning are: (1) clear view about the positive interdependence; (2) supportive interaction (face-to-face); (3) clear view about individual responsibility and personal responsibility to achieve group goals; (4) frequently using small group skills and relevant interpersonal skills; (5) frequent and regular group processing towards current functions to develop effectiveness in the future [34]. Thus, learning with cooperative learning model involves the use of small groups and students are required to cooperate collaboratively with the goal of maximizing their own learning process and the learning process among the member of the group.

\section{THE RELATIONSHIP BETWEEN TEACHER'S COMPETENCE AND CONSTRUTIVISM LEARNING}

The competence of the mathematics teacher is related to the science which contains the knowledge and skills applied in an action, namely the practice of mathematics. The abilities contained in the competence of practice are solving problems, presenting ideas, communicating, connecting and verifying through reasoning. This ability in mathematics learning is called the power of math [35]. Power of math must not only be mastered by the students, but it must be mastered by the teacher as well.

Teachers teach and educate students with the right method of learning, which is based on the constructivism learning theory, therefore the students can master the power of math, one of which is communication. One of the benefits of constructivism learning is to develop the communication of the student, that enables the students to actively construct their own knowledge [20].

When students implement constructivism learning, the teacher will simultaneously master the power of math as well. Power of math is a small portion of competence that must be possessed by the teachers. Such competence has no benefit if it is not applied in mathematical practice. This indicated that the competence of mathematical practice and constructivism learning need each other. Competence of mathematical practice is modeled by a theory. Constructivism learning is defined as a learning experience. A theory without experience may be misdirected as practice competence can underestimate various effects of situational factors. Whereas, experience without theory frequently becomes useless and potentially disadvantageous because the practice of mathematics without the competence of practice may resulted in the practice of 'trial and error' only until the success is achieved. Mathematical 
practice has its own difficulties for teachers. It also emerged that $66 \%$ of teachers often face difficulties whilst performing their duties. With regard to teaching methodology, 3 out of 4 teachers find it difficult to use new technology when teaching, to organize activities outside the classroom, or to adopt pedagogical theories [36]. Difficulties will increase if teachers do not possessed the practical competence in the application of constructivism learning.

\section{CONCLUTION}

One task of mathematics teachers is the practice of mathematics. The implementation of mathematical practice requires the competence of mathematical practice. Competence of mathematical practice involves several aspects, one that must be mastered by the teacher is the power of math. Teacher's power of math is applied in constructivism learning, therefore students can master the power of math as well. Mathematics teachers are required to have the competence of mathematical practice, therefore the practice of mathematics in constructivism learning can achieve the expected learning objectives.

\section{REFERENCES}

[1] OECD Data, Teachers, 2016.

[2] A. Juvova, S. Chudy, P. Neumeister, J. Plischke, J. Kvintova, "Reflection of constructivist theories in current educational practice, "Universal Journal of Educational Research, vol. 3(5), pp. 345-349, 2015.

[3] T. Ghaye, Teaching and Learning through Reflective Practice: A Practical Guide for Positive Action 2th Ed, Abingdon, UK: Routledge, 2011.

[4] UCLES, Developing Your School with Cambridge: A Guide for School Leaders, England: Cambridge Assesment International Education, England, 2015.

[5] Sumarsih, "Implementasi teori pembelajaran konstruktivistik dalam pembelajaran mata kuliah dasar-dasar bisnis," Jurnal Pendidikan Akuntansi Indonesia, vol. VIII (1), pp. 54-62, 2009.

[6] UNESCO, The four pillars of learning.

[7] S. Danim, Pengembangan Profesi Guru: dari Pra-jabatan, Induksi, Keprofesional Madani. Jakarta: Kencana Prenada Media Group, 2011.

[8] M. Sembiring \& M. Gorky, Mengungkap Rahasia dan Tips Mengajar Menjadi Guru Sejati. Yogyakarta: Best Publisher, 2009.

[9] Janawi. Metodologi dan Pendekatan Pembelajaran. Yogyakarta: Ombak, 2013.

[10] J. Huber \& C. Reynolds. Developing Intercultural Competence through Education. Perancis: Council of Europe Publishing, 2014.

[11] NCTM, NCTM CAEP Mathematics Content for Elementary Mathematics Specialist Addendum to the NCTM CAEP Standards, 2012.

[12] Indonesia. Peraturan Pemerintah Republik Indonesia tentang Standar Nasional Pendidikan No. 19 Tahun 2005.

[13] Australian Institute for Teaching and School Leadership, Professional Knowledge, 2017.

[14] D. H. Schunk, Learning Theories An Education Perspective Teori-teori Pembelajaran Perspektif Pendidikan Edisi Keenam, Yogyakarta: Pustaka Pelajar, 2012.

[15] J. R. H. Tudge, J. R. H. \& S. Scrimsher, "Lev S. Vygotsky on education: a cultural-historical, interpersonal and individual approach to development in Educational Psychology: a century of contributions," Mahwah, New Jersey: Lawrence Erlbaum Associates, 2003, pp. 207-228.
[16] R. W. Dahar, Teori-teori Belajar dan Pembelajaran. Jakarta: Erlangga, 2011.

[17] Y. Karagiorgi \& L. Symeou, "Translating constructivism into instructional design: potential and limitations," Educational Technology \& Society, vol. 8(1), pp. 17-27, 2005.

[18] R. J. Amineh \& H. D. Asl, "Review of constructivism and social constructivism, "Journal of Social Sciences, Literature and Languages, vol. 1(1), pp. 9-16, 2015.

[19] M. G. Jones, "The impact of constructivism on education: language, discourse, and meaning," American Communication Journal, vol. 5(3), 2002.

[20] S. O. Bada, "Constructivism learning theory: a paradigm for teaching and learning," IOSR Journal of Research \& Method in Educatiom, vol. 5(6) vers. 1, pp. 66-70, 2015.

[21] Indonesia. Peraturan Pemerintah Republik Indonesia tentang Kerangka Dasar dan Struktur Kurikulum Sekolah Menengah Kejuruan/Madrasah Aliyah Kejuruan, Nomor 70 Tahun 2013.

[22] G. R. McPherson, "Teaching \& learning the scientific method," The American Biology Teacher, vol. 63(4), pp. 242-245, 2001.

[23] E. Soviawati, "Pendekatan matematika realstik (pmr) untuk meningkatkan kemampuan berfikir siswa di tingkat sekolah dasar," Jurnal Pendidikan ke-SD-an Edisi Khusus No. 2, pp. 79-85, 2011.

[24] H. Freudental, Revisiting Mathematics Education. London: Kluwer Academic, 2002.

[25] A. Treffers, Three Dimensions A Model of Goal and Theory Description in Mathematics Instruction-The Wiskobas Project, Tokyo: D. Riedel, 1987.

[26] Sumaryanta, "Pembelajaran matematika realistik dan strategi implementasinya di kelas,"Jurnal PPPPTK Matematika Kementerian Pendidikan dan Kebudayaan, 2013.

[27] Hasnawati, "Pendekatan contextual teaching learning hubungannya dengan evaluasi pembelajaran,'Jurnal Ekonomi \& Pendidikan, vol. 3(1), pp.53-62, 2006.

[28] S. Sears, Introduction to Contextual Teaching and Learning, Indiana: Phi Delta Kappa Educational Foundation, 2003.

[29] N. Hanafiah \& C. Suhana, Konsep Strategi Pembelajaran, Bandung: Refika Aditama, 2012.

[30] Hmelo, E. Cindy \& Silver, "Problem based learning: what and how do students learns," Educational Psychologu Review, vol. 16(3), pp. 235266, 2004.

[31] Hosnan, Pendekatan Saintifik dan Kontekstual dalam Pembelajaran Abad 21, Bogor: Ghalia Indonesia, 2014.

[32] R. M. Capraro \& S. W. Slough, Why PBL? Why STEM? Why Now? An Introduction to STEM Project Based Learning: An integrated Science, Technology, Engineering and Mathematics (STEM) Approach, Netherlands: Sense Pusblisher, 2013.

[33] H. S. Saefuddin, I. Berdiati, Pembelajaran Efektif, Bandung: Remaja Rosdakarya, 2014.

[34] D. W. Johnson, R. T. Johnson \& E. J. Holubec, Colaborative Learning Strategi Pembelajaran untuk Sukses Bersama, Bandung: Nusa Media, 2012.

[35] NCTM, Principles and Standards for School Mathematics, United States of America: The National Council of Teachers of Mathematics, Inc, 2000.

[36] M. Liakopoulou, "The professional competence of teachers: which qualities, attitudes, skills and knowledge contribute to a teacher's effectiveness?," International Journal of Humanities and Social Science, vol. 1(21), pp. 66-78, 2011. 